\title{
Change in Power in the Media and Innovative Ways to Do Politics in Mexico*
}

\author{
Cambio de poder en los medios y formas novedosas de hacer política en México
}

\author{
David Ramírez Plascencia ${ }^{a}$ \\ Universidad Virtual de la Universidad de Guadalajara, \\ México \\ david.ramirez@redudg.udg.mx \\ ORCID: https://orcid.org/0000-0003-3287-8769
}

DOI: https://doi.org/10.11144/Javeriana.papo25.cpmf

Received: 08 November 2019

Accepted: 15 April 2020

Published: 03 December 2020

\begin{abstract}
:
The advent of internet and other similar technologies has changed the traditional social and political relationships. Since 2015, in Mexico, some election wins have showed that it is possible to win without any support from the mainstream media or, indeed, without being backed by a big political party. Most of the political campaign is then developed through the social networks and digital activism. This article is mainly aimed at understanding the impact of the social networks on the design of campaign strategies, i.e., how to conciliate the interests from different actors and elites in a new hyperconnectivity context.
\end{abstract}

Keywords: power and media, elites in Mexico, social networks, digital activism, independent candidate.

\section{Resumen:}

La llegada de Internet y otras tecnologías similares ha alterado las relaciones sociales y políticas tradicionales. En México desde el año 2015, algunas victorias electorales han demostrado que es posible ganar sin el apoyo de los medios tradicionales de comunicación, o incluso sin el respaldo de un gran partido político, apostando gran parte de la campaña política en las redes sociales y el activismo digital. El objetivo principal de este trabajo es comprender el impacto de las redes sociales en el diseño de las estrategias de campaña, la armonización de los intereses de los actores y las élites en un nuevo contexto hiperconectado.

Palabras clave: poder y medios, élites en México, redes sociales, activismo digital, candidatos independientes.

\section{Introduction}

Digital technologies as the Internet, mobile devices and social media present new challenges for local and international governments that have witnessed how these technological advances reshape traditional social and political institutions, establishing new forms of association and interaction based on the connectivity. Traditional media corporations have been forced to integrate digital tools to their productive chains, and to reconsider their financial model. For newspapers, this transition has been dramatic. In a matter of a few years most of them have been compelled to mutate from paper to bits, and to adopt a new monetary model based on online advertising, "clickbaits" and "shares". However, not all traditional newspapers have survived this transition. In recent years, more than 1 in 5 newspapers have closed in the United States (Takenaga, 2019). At the same time, social platforms such as Facebook, YouTube or Twitter, have become the main source for online news (Martin, 2018). Activists and political parties are less dependable on traditional media like television and more reliable on the use of social media and online political engagement, as in the case of Donald Trump's electoral winning in the USA, which was based on the use of Twitter (Bulman, 2016). Considering television, the irruption of digital platforms like YouTube, Hulu and Netflix has transformed the video consumption market as we have known it. Every day, more consumers are cancelling their cable provider contracts and moving to the streaming on-demand services (FitzGerald \& Rizzo, 2020). In the US, for example, cable and satellite companies lost 5.5 million subscribers in 2019. In Mexico, increasing levels of social media adoption has sponsored the influx of several digital content services from Facebook, YouTube, Twitter and

\section{Author notes}

\footnotetext{
${ }^{a}$ Corresponding author. E-mail: david.ramirez@redudg.udg.mx
} 
WhatsApp to Netflix, Apple Music and Spotify ("Latin America OTT", 2018). This transition from traditional media (Television, Radio, Newspapers) towards streaming entertainment services has triggered important changes in politics as well.

Traditionally, there has been a strong link between the government and the mass communication media, particularly with broadcasting corporations (Televisa and TV Azteca). This association compromised the operation of TV channels to support an electoral candidate: to extol the achievements of a public server or political party and to criticize the opposition. In exchange, the ruler party delivers privileges to the corporations in the form of tax exemptions and huge investments in marketing. However, this traditional alliance between political and mass media elites has been compromised. Electoral victories of independent candidates in 2015 (Lagunes López et al., 2016), as the case of Pedro Kumamoto a local deputy in Jalisco State and Jaime Rodríguez the governor of Nuevo León, have showed that it is possible to win an election without the support of traditional broadcasting companies or even the backing of a big political party, founding the political campaign on social media. This trend, however, was not a "transient trend". On the contrary, it was a constant in the next 2018 local and federal elections in the country. Indeed, in the 2018 Mexican election there were 47 independent candidates (Franco, 2018).

Although, far from thinking about a decisive decline of the customary political and media corporation elite's covenants, the purpose of this article is to emphasize that besides the technological changes, controlling the media is still an imperative for elites. Nevertheless, this battle will be played on a new "battlefield", including new fresh players like big technology corporations and independent candidates, forcing the elites to reconsider their traditional strategy to preserve their privileges. This text will focus on the analysis of two relevant cases when the winners based their campaign mainly on alternative media, without the backing of a big political party: a) Pedro Kumamoto (Mexico's first independent state deputy), and b) Jaime Rodríguez "El Bronco" (Mexico's first independent governor). The main aim is to understand the role of social media in the design of the campaign strategy, the harmonization of actors and elites' interest to the new political context, and how these new arrangements and novel forms of doing politics will encourage the conformation of inventive communication strategies and elites' alliances between fresh and traditional actors, especially with the proliferation of independent local and federal candidates for the 2018 elections in Mexico.

\section{Theoretical Background}

The modern notion of "elite", a group of people that monopolize and exercise power or that have a deep influence in the process of decision-making regarding public affairs, could be rooted to the last decade of the 19 th century and the beginning of the 20th century with the seminal works by Gaetano Mosca, Vilfredo Pareto, and Robert Michels (Hartmann, 2006; Bottomore, 1993). Elites, as Mills (2000) has pointed, need the assistance of a sub-elite or second stratum to seize power: scientists, white-collar workers, and thinkers among other groups. Besides the imperative of studying the sub-classes that back the elite's control. Another central point regarding the elites is the fact that these groups do not remain stationary but, on the contrary, after a certain time, they rotate, producing during this readjustment, important social and political changes. For this reason, it is crucial to clarify how a particular individual or group could lose their position, and how others could enter into this select group or, in other words, to identify the dynamics that structure the circulation of the elites in a given community or country. This fight to control and retain the power, however, is not a particular phenomenon inside oppressive regimes or organizations. Furthermore, as Robert Michels unveils (1999), these events occur inside every political and social organization, even in those showing off as democratic and egalitarians.

Following Mosca (1923), the wealth is the foundation of the political power. Still, what is remarkable in the 21 st century is how the source of wealth is moving from commodities and industries to the digital 
economy. This shift could be appreciated particularly in the rise of transnational digital corporations, a new global elite that centers its power in the acquisition and control of information. By now, the first five most important companies in the world: Apple, Alphabet (Google), Microsoft, Amazon and Facebook are related with information technologies and communication services. However, this power shift is not lacking a controversy. In recent years, the opinion about social platforms has changed dramatically. From a positive consideration that envisages them as an instrument of civic engagement, spaces where people have access to more horizontal and less controlled information (Dylko et al., 2012), and that have heartened libertarian movements as the Arab Spring in 2010 or the public mobilization as the case of \#MeToo in 2017 or The Yellow vests movement in 2018. Actually, people have a more critical view towards social media (Haig, 2017). Thanks to the Donald Trump electoral victory, the expansion of extremist political parties in the United States and Europe, the phenomenon of "Fake News" and the formation of big digital media monopolies, there are opinions that question those benefits, and that consider the increasing power of big digital media corporations as a threat to democracy ("How to tame", 2018). In addition, public opinion tends to forget that digital media, as in the case of the analogic ones, is susceptible of being used by elites to frame reality (Kerby \& Marland, 2015). One common strategy employed by the elites to get favorable legal and political outcomes or to avoid the promulgation of laws contrary to their interests is to set lobbying campaigns (Goldstein, 1999; Andersson \& Calvano, 2015). This, of course, is not a new practice. Long before the arrival of social media, elites profusely used traditional media (newspapers, radio and television) to save their interests (NeJaime, 2011). Nonetheless, this new interconnected context, in where international corporate networks and the interchange of digital goods play a crucial role, has compromised the prominence of traditional media elites which are trying to fight back to avoid losing their privileges. Following Pareto (1978) when an elite cannot stand its privileges and positions, it is in decadence, then it is removed by another one. This reality has reached traditional media corporations like Televisa in Mexico that now faces a more competitive market shaped by the on-demand model used by companies like Netflix, HBO or Amazon Prime. But political elites who based their power in the control of political parties are now facing a more diverse and fragmented scenario marked by the profuse use of information technologies as well. This new landscape settles important changes regarding the traditional power alliance between elites: politicians and media corporations. Though, what is interesting here, is not the elites' attempt to control and use social media to protect their privileges but how digital media configures their strategy (Freedman, 2015) and the way of doing politics and activism, particularly regarding elections (Jacobs \& Spierings, 2016; Chen, 2015).

The Internet has had a deep impact reconfiguring the traditional alliance between media corporations and political parties. Recent electoral triumphs, like in Mexico, has shown that it is possible to win even without the support of traditional political and media elites. This, however, does not mean a breaking point regarding the relation between elites and masses, where social media will bring a radical democratic shift but, on the contrary, this panorama sets a new context where traditional media corporations and political parties are compelled to forge novel alliances with fresh players and to develop alternative strategies where the chances of winning an election stand mainly based on two important facts: a) what way information technologies provide vital information regarding electoral preferences, and $b$ ) how social media give a significant impulse to independent and official candidates (Van Aelst \& Walgrave, 2016). One key purpose of this paper is to describe how traditional media and political elites in Mexico are struggling to retain their power and privileges in a changing context where social media corporations and independent candidates are emerging in the political landscape. 


\section{Mexico: global aperture, novel players and traditional elite's struggle}

The detriment of central national power, the progression of local elites, global capitalism and the consolidation of international digital media corporations encouraged the arrival of a new kind of coalition: the global elites. These new groups are characterized by three main aspects (Kakabadse et al., 2012): 1) a deep interest in acquiring foreign land and resources, b) the proliferation of proxy wars, particularly in Africa and the Middle East, and c) a stressed multi-porality, where global elites establish diverse networks to negotiate and to progress their private agendas, trying to avoid confrontation with each other. In the case of media, digital global elites, like Alphabet (Google) and Facebook, have become a threat to the traditional media elites who have played a predominant role in configuring the political landscape in many countries for decades. The shift to the on-demand model compromises not only their position, but even their survival in the market.

In Latin America, after decades of ferrous political and economic control, the region started a process of economic and democratic aperture. The import substitution industrialization (ISI) model entered in crisis during the 1980 decade due to these main factors: a) a huge trade deficit molded by protectionism and the lack of incentives to research and to innovate, b) public fiscal imbalances and the weakness of its economics resources and c) monetization deficits and huge economic inflation (Jarquín \& Echebarría, 2007). This period announces the end of military regimens in several countries like Argentina and Chile, and in the case of Mexico, after more than seventy years, there was an electoral shift in the presidency in 2000. There were important privatizations of state companies in diverse sectors like communications, agriculture and public services, and a huge incoming of international private investments (Teichman, 2001). However, this economic openness has not yet established the consolidation of transnational corporate elites in the region. Additionally, the regional market has developed a double nature: on one side it is transnational in terms of transactions but is still national in terms of management. All these facts disturb the possibility to forge a coherent regional project (Cárdenas, 2015). Corporate elites in Latin America have huge power in their national market, but they are not so competitive in global marketplaces (Cárdenas, 2016). This lack of competitiveness and the consolidation of national monopolies in the media sector compromised the continuity of traditional media elites that were ill-equipped to face a more diversified and competitive scenario based on digital services and social media platforms. In Mexico, for example, legal and political barriers relented for decades the arrival of novel players to the media and telecommunication market and encouraged the consolidation of hegemonic groups: a duopoly regarding media, Televisa and TV Azteca, and a monopoly, TELMEX, considering telecommunications (Rentería, 2007). This situation disheartened competition and innovation in those sectors. However, the panorama has changed. After the entrance of digital media companies like Netflix and Spotify, the economic balance of some powerful traditional media companies as the case of Televisa is now in red numbers and its predominance is compromised (Ganuza $\&$ Viecens, 2014). But media elites are not alone in this struggle, political elites face a more varied and challenging panorama for the local and federal elections in 2018. They are trying to restructure a traditional inherited model of doing politics that has survived throughout the 20th century, named by Mario Vargas Llosa, the Literature Nobel Prize winner in 2010, as "The perfect dictatorship".

For decades, El Partido Revolucionario Institucional (The PRI - Institutional Revolutionary Party) ruled Mexico without much opposition until the year 2000. This political party managed to remain in power thanks to a complex network of political, social and economic institutions and organizations. The party was successful in incorporating diverse social classes and group interests, many of them with contradicted ideologies among each other (Rosenberg, 2001). The PRI encouraged the forge of corporatist structures through the foundation of labor unions, leagues and associations. This was the case of the Confederación de Trabajadores de México - CTM - The Confederation of Mexican Workers). Those associations were sponsored by interest groups that, in exchange of some privileges, reinforced PRI's electoral conquests. This corporatist structures allowed the party to achieve political and social stability, and a balance between elites 
that lasted for seven decades. Though, after two huge economic crises, one in 1982 and another in 1994, Mexico entered a process of political decentralization whereby power, resources and responsibilities where shared among counties and states. This change allowed spaces of political contestation against the central power (Falleti, 2010). The Mexican subnational political panorama became less controlled and fragmented, and local economic and political elites gained more autonomy.

Traditionally, the Mexican political system has been shaped by the existence of three major political parties and other minor parties that eventually forge alliances among them (Palma, 2010). However, for decades, this system was a simulation because, after the electoral fight, candidates backed by the hegemonic party usually won. Actually, a more exposed political system, the existence of alternative communication media and the rise of independent candidates have forced traditional larger parties to rethink their strategy for the future elections, as the case of the 2018 presidential election. They have even established alliances with other antagonist political parties that do not share a common ideology, particularly the coalition between the PAN (Partido Acción Nacional - National Action Party, right wing), the PRD (Partido de la Revolución Democrática - Party of the Democratic Revolution, left wing) and the MC (Movimiento Cuidadano Citizens' Movement, social-democrat). Many politicians have changed their loyalty to other political parties in order to preserve their privileges (Kerevel, 2014), and some of them have even undertaken a long path as independent competitors trying to fill their political expectations under this formula. This is the case of Margarita Zabala that lost the PAN presidential candidate nomination, finally the party preferred Ricardo Anaya that was the presidential candidate under the coalition among PAN, PRD and MC, "Por México al Frente" (For Mexico to The Front). This new context blurred the line between political adversaries and ideologies in order to expand the possibilities to win in what was probably the most competitive political scenario in the modern history of the country. However, elections of 2018 were shaped by skepticism and the lack of trust regarding public institutions and political parties. Mexicans were reluctant to vote for candidates backed by traditional candidates and old-style media like television and newspapers (del Tronco, 2012; Natal, 2017). This explains the success of political projects that based their campaigns on social media, civil associations and charismatic leaders backed by small parties. This is the case of Andrés Manuel López Obrador, who was eventually elected as the Mexican President on July 01, 2018.

\section{Methodology and Analysis}

This research aims to outline the effects of information technologies on the Mexican political landscape, particularly how the prolific use of social media in electoral campaigns has impacted the way political parties configure their strategy for elections, and how the transition from analogic communications (radio, television and paper-based newspapers) to digital media (social media, mobile devices, etc.) impacts the traditional alliance between elites in the country. For decades, national media corporations and political parties forged an alliance where the media framed public opinion to back governmental actions and to support official candidates. In exchange, media corporations get tax exemptions and huge advertising contracts from the government. However, the electoral victories of candidates, without the sponsorship of customary media or a big political party, provides new challenges for traditional elites that now are compelled to cope with novel players on the board. Fieldwork will explore two relevant electoral victories of autonomous candidates in 2015. Their political campaign was marked not only by a lack of a political party's backing, but also by the absence of significant traditional media support. Case A, the electoral victory of Pedro Kumamoto in the State of Jalisco, Mexico's first independent state deputy. Case B, how Jaime Rodríguez "El Bronco" was elected as Mexico's first independent governor in the northern State of Nuevo León. This text will put special efforts to identify a) the factors that shaped the electoral process in both cases, b) how the electoral outcome affected the elite's interests (Hughes \& Cormode, 1998), and c) the role of information technologies in the electoral 
campaign (Gabel \& Scheve, 2007), particularly the impact of social media encouraging political engagement (Freelon et al., 2016).

Between 2012 and 2014 there were important constitutional reforms in Mexico. The legal changes allowed candidates without the backing of a political party to participate in federal and local elections. Three years later, in 2015, two significant wins of independent candidates showed how, besides complexities and obstacles to fulfill the requirements to become an external candidate, it was possible to succeed in a campaign against opponents backed by strong parties and with a copious presence in traditional media like the radio and television. Pedro Kumamoto won the election of the 10th district in the city of Zapopan, a city in Jalisco. He succeeded with more than 50,000 votes and defeated strong political parties like the PRI (Centre) and the PAN (Partido Acción Nacional - National Action Party (right wing). The PAN has won all precedent elections in that political jurisdiction. Kumamoto was supported by a civil organization called "Wikipolitica". As its name denotes, this organization impulses political projects in a collaborative way as the case of the famous online encyclopedia (Wikipedia). The independent candidature of Pedro Kumamoto, a former student leader, was the first political project of Wikipolitica. This alternative project won the election with only few economic resources. They only allowed private donations of 7000 pesos (about 400 dollars). At the end, Kumamoto spent about 9,600 dollars throughout the entire campaign. Some of his opponents backed by political parties, on the contrary, spent four times that amount (Corona, 2015).

In the second case, Jaime Rodríguez Calderón "The Bronco", won in 2015 the governor election in Nuevo León, one of the richest states in Mexico, without the backing of one traditional party and with little investments in traditional media. However, contrary to what happened with Pedro Kumamoto, who did not have a trajectory inside a political party. "The Bronco" has a long background inside the PRI, he was local deputy and then mayor of García Municipality. However, after three decades as PRI's militant, he resigned and announced that he will search the governor candidature only with the support of an independent platform, as the case of Pedro Kumamoto, called Cerebro, Corazón y Carácter (Brain, Heart and Character). By now, this platform as the case of Wikipolitica, is backing other candidates in diverse local and federal elections. Three years after those victories, both politicians completed the requirements to participate in the 2018 elections. Kumamoto obtained 100,000 signatures across the State of Jalisco to be considered as a candidate to the Mexican senate. In the case of "The Bronco", he had to obtain 1\% of the total electoral roll in 17 of the 32 states in the country (About 900,000 signatures). These requirements clearly tend to discourage the irruption of independent candidates. However, besides the obstacles, the number of candidates at all levels is rising. On October 2017, there were 86 citizens that looked for signatures (Hootsen, 2017). They have the advantage of using social media to support the process to gather the signatures, and the possibility to practice a straighter way of political promotion even before the formal beginning of the election. From a certain point of view, a citizen's signature backing the aspirations of a candidate could become a vote for the next elections. Many people are willing to vote for candidates that work hard to obtain a place rather than those candidates who were just chosen by a political party. The campaign to get the signatures is also a formula to weigh the real possibilities of a proposed candidate for the next election. Contemplating both cases, it is possible to understand important lessons for future elections in Mexico and beyond: (1) a huge investment of resources and the support of traditional parties, even from the party that has won all past elections, does not guarantee an electoral triumph (2) Another important lesson is that a political project founded on civil mobilization and social media engagement could compete with official candidates, mainly because digital platforms are as effective as traditional ones to brand the contender. This, however, does not mean that traditional media are obsolete; rather, it means that supporting a political campaign merely in those spaces is not enough to win. It is important to implement novel forms to promote civic engagement using social media. In Jalisco's local election in 2015, Pedro Kumamoto used only two television spots (Alcalá \& Reynaga, 2017). In Nuevo León, "El Bronco" established a similar strategy. He spent little resources in television and almost all the political campaign was raised on social media (Howard et al., 2016). (3) In a 
context of skepticism towards political parties, especially concerning the traditional ones, recent elections pose an important dilemma, not only for the electoral landscape in Mexico but across Latin America: how to merchandise the candidate over the political party, and to succeed in spite of the disbelief in traditional parties. (4) Independent candidates stand a real peril for some traditional elites, particularly for those who link their power to the support of traditional parties. They are now facing the fact that being backed by a strong political party is not a guarantee to get political power and to preserve their privileges. And (5) the irruption of novel parties with charismatic politicians as the case of MORENA (Movimiento Regeneración Nacional - National Regeneration Movement) and Andrés Manuel López Obrador, and the proliferation of politicians that look for opportunities as independent candidates clearly indicated a trend to diversification in the political landscape in Mexico.

\section{Conclusion}

In the 21 st century, the digital interconnected reality is a point of no return. Social media have dramatically changed the way of doing journalism and politics as well (Jeffares, 2014). In Mexico, the growing levels of Internet connectivity, the arrival of global digital media corporations into the market and a new political landscape marked by the fragmentation of power and the diversification of players pose important dilemmas and complexities for traditional elites. However, what is important to recall is how these international and local shifts will condition the traditional elite's strategies to uphold their privileges in a more diverse and competitive market and political context.

A key topic is how traditional media and political elites are trying to survive in a context where their assets are less determinant to influence the election outcomes as it used to be in the past. In the case of traditional media, their privileges and positions are under attack mainly by two important facts: (a) a shift in the model of consumption contents from analogical to digital; (b) the losing of preponderance by traditional media in the political campaign, which is moving towards a model of social media engagement, more accessible, collaborative and cheaper. This situation undermines the power of media corporations to negotiate with political elites and interest groups, forcing them to incorporate novel economic models beyond the founding of political parties and governments. Indeed, Televisa is moving to the on-demand model with its platform BLIM, betting for the production of novel contents to compete in the market. But traditional parties are facing more competition and losing the monopoly to access the political power as well. The independent candidates are facing diverse possibilities for novel elites and interest groups that could now back political ventures to fill their expectations.

However, resuming Michels' theoretical assumptions to analyze actual decentralized political movements that back independent candidates, it is possible to highlight a critical anomaly that compromises democracy inside those groups: the more organized they are, they tend to be more oligarchic and undemocratic. At the end, those movements will eventually adopt the internal structure of traditional political parties, including the formation of elites inside them. This is what happened with Pedro Kumamoto that, after a frustrating electoral outcome in 2018, he founded a political party called "Futuro" (future in English) (Solís, 2020). Cases as Kumamoto illustrate well how many of those independent candidates will be eventually constrained, disposed or not, to join novel or traditional elites to stand their position, sometimes even losing the control of their own political agenda, forced to assume and protect other players and elite's interests. Though this does not necessarily mean the perpetuation of the traditional elites but, on the contrary, that novel players in the board will boost significant social and political changes in Mexico. The aftermath of the 2018 elections brought more clarity to the future of Mexican political landscape in the forthcoming years, dividing winners and losers, but what is not in question is that the board, the strategies and, even some players, have changed. 


\section{References}

Alcalá Anguiano, F., \& Reynaga Berumen, P. (2017). Las estrategias persuasivas en la propaganda electoral. Análisis de los spots televisivos transmitidos durante la campaña electoral Jalisco 2015. Comunicación y Sociedad, 29, 17-39. http://www.scielo.org.mx/scielo.php?script=sci_abstract\&pid=S0188-252X2017000200017\&lng $=\mathrm{es} \& \mathrm{nrm}=\mathrm{iso}$

Andersson, L., \& Calvano, L. (2015). Perceived mobility of impact: Global elites and the bono effect. Critical Perspectives on International Business, 11(2), 122-136. https://doi.org/10.1108/cpoib-10-2012-0046

Bottomore, T. (1993). Elites and Society (2nd edition). Routledge.

Bulman, M. (2016, November 28). Donald Trump's "celebrity-style" tweets helped him win US presidential election, says data scientist. The Independent. https://www.independent.co.uk/news/world/americas/donald-trump-tw itter-account-election-victory-president-elect-david-robinson-statistical-analysis-a $7443071 . \mathrm{html}$

Cárdenas, J. (2015). Are Latin America's corporate elites transnationally interconnected? A network analysis of interlocking directorates. Global Networks, 15(4), 424-445. https://doi.org/10.1111/glob.12070

Cárdenas, J. (2016). Why do corporate elites form cohesive networks in some countries, and do not in others? Crossnational analysis of corporate elite networks in Latin America. International Sociology, 31(3), 341-363. https: //doi.org/10.1177/0268580916629965

Chen, P. J. (2015). New Media in the Electoral Context: The new normal. In C. Johnson, J. Wanna, \& H.-A. Lee (Eds.), Abbott's Gambit (pp. 81-94). ANU Press.

Corona, S. (2015, June 9). Pedro Kumamoto, el candidato de los 500 dólares, vence en Jalisco. El País. https://elpais. com/internacional/2015/06/09/actualidad/1433802253_665446.html

Del Tronco, J. (2012). Las causas de la desconfianza política en México. Perfiles Latinoamericanos, 20(40), 227-251. h ttp://www.scielo.org.mx/pdf/perlat/v20n40/v20n40a9.pdf

Dylko, I. B., Beam, M. A., Landreville, K. D., \& Geidner, N. (2012). Filtering 2008 US presidential election news on YouTube by elites and nonelites: An examination of the democratizing potential of the internet. New Media \& Society, 14(5), 832-849. https://doi.org/10.1177/1461444811428899

Falleti, T. G. (2010). Decentralization and Subnational Politics in Latin America. Cambridge University Press.

FitzGerald, D., \& Rizzo, L. (2020, February 20). Cord-Cutting Accelerated in 2019, Raising Pressure on Cable Providers. Wall Street Journal. https://www.wsj.com/articles/cord-cutting-accelerates-raising-pressure-on-cabl e-providers-11582149209

Franco, M. (2018, April 4). Los nuevos independientes de México, ¿la misma política de siempre? The New York Times. https://www.nytimes.com/es/2018/04/04/espanol/america-latina/mexico-elecciones-independientescandidatos.html

Freedman, D. (2015). Media Moguls and Elite Power. The Political Economy Research Centre.

Freelon, D., McIlwain, C., \& Clark, M. (2016). Quantifying the power and consequences of social media protest. New Media \& Society, 20(3), 990-1011. https://doi.org/10.1177/1461444816676646

Gabel, M., \& Scheve, K. (2007). Estimating the Effect of Elite Communications on Public Opinion Using Instrumental Variables. American Journal of Political Science, 51(4), 1013-1028. https://doi.org/10.1111/j.1540-5907.200 7.00294.x

Ganuza, J. J., \& Viecens, M. F. (2014). Over-the-top (OTT) content: Implications and best response strategies of traditional telecom operators. Evidence from Latin America. Info, 16(5), 59-69. https://doi.org/10.1108/info $-05-2014-0022$

Goldstein, K. M. (1999). Interest Groups, Lobbying, and Participation in America. Cambridge University Press.

Haig, M. (2017, September 6). I used to think social media was a force for good. Now the evidence says I was wrong. The Guardian. https://www.theguardian.com/commentisfree/2017/sep/06/social-media-good-evidence-platf orms-insecurities-health

Hartmann, M. (2006). The Sociology of Elites. Routledge. 
Hootsen, J.-A. (2017, November 3). Independent candidates threaten to break grip of Mexico's parties in next election. America Magazine. https://www.americamagazine.org/politics-society/2017/11/03/independent-candidatesthreaten-break-grip-mexicos-parties-next

How to tame the tech titans. (2018, January 18). The Economist. https://www.economist.com/news/leaders/21735 021-dominance-google-facebook-and-amazon-bad-consumers-and-competition-how-tame

Howard, P. N., Savage, S., Saviaga, C. F., Toxtli, C., \& Monroy-Hemández, A. (2016). Social Media, Civic Engagement, and the Slacktivism Hypothesis: Lessons from Mexico's "El Bronco". Journal of International Affairs, 70(1), 55. https://jia.sipa.columbia.edu/social-media-civic-engagement-and-slacktivism

Hughes, A., \& Cormode, L. (1998). Researching Elites and Elite Spaces. Environment and Planning A, 30(12), 2098-2100. https://doi.org/10.1068/a302098

Jacobs, K., \& Spierings, N. (2016). Social Media, Parties, and Political Inequalities. Palgrave Macmillan.

Jarquín, E., \& Echebarría, K. (2007). The Role of the State and Politics in Latin American Development (1950-2005). In M. Payne, D. Zovatto, \& M. M. Diaz (Eds.), Democracies in Development: Politics and Reform in Latin America (pp. 1-14). Inter-American Development Bank.

Jeffares, S. (2014). Interpreting Hashtag Politics: Policy Ideas in an Era of Social Media. American Institute of Aeronautics and Astronautics.

Kakabadse, N. K., Kakabadse, A., \& Kouzmin, A. (2012). From Local Elites to a Globally Convergent Class: A Historical Analytical Perspective. In N. Kakabadse \& A. Kakabadse (Eds.), Global Elites: The Opaque Nature of Transnational Policy Determination (pp. 1-38). Palgrave Macmillan.

Kerby, M., \& Marland, A. (2015). Media Management in a Small Polity: Political Elites' Synchronized Calls to Regional Talk Radio and Attempted Manipulation of Public Opinion Polls. Political Communication, 32(3), 356-376. h ttps://doi.org/10.1080/10584609.2014.947449

Kerevel, Y. P. (2014). Loyalty and Disloyalty in the Mexican Party System. Latin American Politics and Society, 56(3), 93-117. https://doi.org/10.1111/j.1548-2456.2014.00242.x

Lagunes López, O. N., Arellanes Jiménez, P. E., Lagunes López, O. N., \& Arellanes Jiménez, P. E. (2016). Las candidaturas independientes en las elecciones de 2015 en México. Límites legales, éxitos electorales y participación ciudadana. Tla-Melaua, 10(40), 60-86. http://www.scielo.org.mx/scielo.php?script=sci_arttext\& pid $=$ S1870-69162016000200060

Latin America OTT revenues to climb by $\$ 4$ billion. (2018, August 9). Broad Band TV News. https://www.broadba ndtvnews.com/2018/08/09/latin-america-ott-revenues-to-climb-by-4-billion/

Martin, N. (2018, November 30). How Social Media Has Changed How We Consume News. Forbes. https://www.forbes.com/sites/nicolemartin 1/2018/11/30/how-social-media-has-changed-how-we-co nsume-news/\#624ea1ae3c3c

Michels, R. (1999). Political Parties: A Sociological Study of the Oligarchical Tendencies of Modern Democracy. Transaction Publishers.

Mills, C. W. (2000). The Power Elite (2nd edition). Oxford University Press.

Mosca, G. (1923). Elementi di scienza politica. Fratelli Bocca Editori.

Natal, A. (2017). Civil Society and Political Representation in Mexico. In A. Albala (Ed.), Civil Society and Political Representation in Latin America (2010-2015): Towards a Divorce Between Social Movements and Political Parties? (pp. 95-117). Springer.

NeJaime, D. (2011). Convincing elites, controlling elites. In A. Sarat (Ed.), Special Issue Social Movements/Legal Possibilities (Vol. 54, pp. 175-211). Emerald Group Publishing Limited. https://doi.org/10.1108/S1059-4337 (2011)0000054010

Palma, E. (2010). Political Parties and Democratization in Mexico: The Endless Chain of Electoral Reforms. In K. Lawson \& J. Lanzaro (Eds.), Political Parties and Democracy: Volume I: The Americas (pp. 149-172). Praeger.

Pareto, V. (1978). Les systèmes socialistes. Librairie Droz. 
Rentería, M. E. G. (2007). Media Concentration in the Hispanic Market: A Case Study of TV Azteca vs. Televisa. International Journal on Media Management, 9(2), 70-76. https://doi.org/10.1080/14241270701263962

Rosenberg, J. (2001). Mexico: The End of Party Corporatism? In C. S. Thomas (Ed.), Political Parties and Interest Groups: Shaping Democratic Governance (pp. 247-269). Lynne Rienner Publishers.

Solís, C. (2020, March 1). Futuro, el partido político que crea Pedro Kumamoto. El Debate. https://www.debate.com .mx/guadalajara/Futuro-el-partido-politico-que-crea-Pedro-Kumamoto-20200103-0197.html

Takenaga, L. (2019, December 21). More Than 1 in 5 U.S. Papers Has Closed. This Is the Result. The New York Times. https://www.nytimes.com/2019/12/21/reader-center/local-news-deserts.html

Teichman, J. A. (2001). The Politics of Freeing Markets in Latin America: Chile, Argentina, and Mexico. The University of North Carolina Press.

Van Aelst, P., \& Walgrave, S. (2016). Information and Arena: The Dual Function of the News Media for Political Elites. Journal of Communication, 66(3), 496-518. https://doi.org/10.1111/jcom.12229

\section{Notes}

* Scientific research article

\section{Licencia Creative Commons CC BY 4.0}

How to cite this article: Ramírez Plascencia, D. (2020). Change in power in the media and innovative ways to do politics in Mexico. Papel Politico, 25. https://doi.org/10.11144/Javeriana.papo25.cpmf. 